\title{
Ethnobotanical Study of Tehsil Kabal, Swat District, KPK, Pakistan
}

\author{
Imtiaz Ahmad, Mohammad Ibrar, Barkatullah, and Niaz Ali \\ Department of Botany, University of Peshawar, Peshawar, Pakistan \\ Correspondence should be addressed to Imtiaz Ahmad, imtiazahmad9310@yahoo.com \\ Received 30 July 2011; Accepted 20 October 2011 \\ Academic Editor: Andrew Wood
}

Copyright () 2011 Imtiaz Ahmad et al. This is an open access article distributed under the Creative Commons Attribution License, which permits unrestricted use, distribution, and reproduction in any medium, provided the original work is properly cited.

A total of 140 plants have been reported ethnobotanically from Tehsil Kabal, Swat District. These include the 133 plants (95\%) of angiosperms, $3(2.14 \%)$ of gymnosperms, and $2(1.42 \%)$ each of pteridophytes and fungi. The largest family is Lamiaceae represented by 11 species followed by Rosaceae represented by 9 species. Among angiosperms 76 (55.63\%) were herbs, 17 (12.78\%) were shrubs, and $40(30.07 \%)$ were trees; 127 plants (95.48\%) were dicot while 6 plants $(4.51 \%)$ were monocot. Most of the plants were used for more than one purpose. Generally the plants were used for medicinal, fuel, timber wood, food, and fodder for cattle purposes.

\section{Introduction}

Ethnobotany is a biological, economic, and cultural interrelationship study between people and plants of an area in which they exist [1]. Ethnobotanical studies focused on contributing to plant biodiversity knowledge (taking into account that the biological diversity as well as human awareness about the uses, applications, and natural resource conservation) on one hand and take this knowledge for further social and scientific interventions on the other hand [2]. Ethnobotanical research also helps in establishment of priorities of local community to ensure that the local values are translated into rational use of resources and effective conservation of biological diversity and cultural knowledge [3]. More than 5000 plant species belonging to angiosperms are used worldwide for medicinal purposes [4]. Medicinal plant products have been used successfully for various ailments both externally and internally. Despite the increasing use of synthetic drugs, plants materials have persisted as the "treatment of choice" as they have no or less side effects [5]. The present study was conducted to explore indigenous knowledge of plants from Tehsil Kabal, Swat District, KPK, Pakistan. Tehsil Kabal, Swat District, Khyber Pakhtunkhwa, Pakistan is located at $34^{\circ} 47^{\prime}$ North and $72^{\circ} 17^{\prime}$ East. Average elevation of the area is about 2400 to 2550 feet.
The inhabitants of the area are mostly connected to farming rearing upon livestock and their products and also on the forest products. Health facilities are scarce, especially in the upper parts of the Tehsil, with only one government hospital situated in the Kabal village. Similar types of studies have also been carried out in KPK and other parts of the country by Abbasi et al. [6], Kamal et al. [7], Ali and Qaiser [8], Ibrar et al. [3], Hussain et al. [9], Bukhsh et al. [10], Qureshi et al. [11], Zabihullah et al. [12], and many others.

It is clear that no such study has been done on the plants of this remote area where residents still use plants to cure various ailments. With the advancement of communication systems and education facilities, the local communities are being exposed to modern facilities, and in most cases, traditional knowledge has been replaced with modern knowledge. The present study was tried to document the traditional knowledge of plants utilization of this area.

\section{Materials and Methods}

The present study was undertaken from August to September, 2010, to document the local uses of some indigenous plants of Tehsil Kabal, Swat, KPK, Pakistan. Information 
TABLE 1: Ethnobotanical information of plants from Tehsil Kabal, Swat District, KPK.

\begin{tabular}{|c|c|c|c|c|c|}
\hline S/no. & Botanical name & Local name & Family & Habit & Ethnobotanical uses \\
\hline (1) & Agaricus campestris L. & Kharerhay & Agaricaceae & Mushroom & Cooked as food. \\
\hline (2) & Adiantum capillus-veneris $\mathrm{L}$. & Sumbal & Adiantaceae & Herb & Leaf decoction, used for cough and fever. \\
\hline (3) & Ajuga bracteosa Wall.ex Benth. & Butey & Lamiaceae & Herb & $\begin{array}{l}\text { The plant is used to relive abdominal pain. Also } \\
\text { used to cure pimples and itch. In the past the } \\
\text { plant was used to treat chicken pox. Some locals } \\
\text { also used it for jaundice. }\end{array}$ \\
\hline (4) & Ajuga parviflora Benth & Butey & Lamiaceae & Herb & $\begin{array}{l}\text { Used in hepatitis, fever, treating tonsillitis, and } \\
\text { other throat problems. }\end{array}$ \\
\hline (5) & Avena sativa $\mathrm{L}$. & Jamdaray & Poaceae & Herb & $\begin{array}{l}\text { Spikes are used as nerve tonic, laxative, and } \\
\text { antiseptic. The plant is also used as fodder. }\end{array}$ \\
\hline (6) & Atropa acuminate Royle. & Bhange Dewana & Solanaceae & Herb & Used as sedative. \\
\hline (7) & $\begin{array}{c}\text { Artemisia scoparaia. Waldst \& } \\
\text { Kitam }\end{array}$ & Jawkay & Asteraceae & Herb & $\begin{array}{l}\text { Young shoots are used as antihelminthic agent } \\
\text { in human and livestock also used for diarrhea. } \\
\text { Mature shoots are used for making brooms and } \\
\text { also used as thatching material. The plant is also } \\
\text { used as fuel. }\end{array}$ \\
\hline (8) & Artemisia absinthium L. & Dhada Tarkha & Asteraceae & Herb & $\begin{array}{l}\text { Shoots are used for typhoid. Also used for } \\
\text { conceiving pregnancy. }\end{array}$ \\
\hline (9) & Alnus nitida (Spach) Endl. & Gheray & Betulaceae & Tree & $\begin{array}{l}\text { Wood is used in timber and making furniture. } \\
\text { Dry leaves are used as fodder for cattle. }\end{array}$ \\
\hline$(10)$ & Alisma plantago_-aquatica L. & Jabai & Alismataceae & Herb & $\begin{array}{l}\text { Leaves are used as tonic, treating diabetes, } \\
\text { dysentery, digestive, and renal problems. Also } \\
\text { used for treatment of leprosy. }\end{array}$ \\
\hline$(11)$ & Alianthus altissima L. & Spena Bakyanra & Simaroubaceae & Tree & $\begin{array}{l}\text { Leaves are used as fodder; wood is used for fuel } \\
\text { and for timber. }\end{array}$ \\
\hline$(12)$ & Achyranthes aspera $\mathrm{L}$. & Spay botay & Amaranthaceae & Herb & Leaves are used as blood purifier. \\
\hline (13) & Acorus calamus L. & Skhawaja & Araceae & Herb & $\begin{array}{l}\text { Rhizome used for stomach inflammation } \\
\text { constipation and other digestive problems. Also } \\
\text { used for asthma. }\end{array}$ \\
\hline$(14)$ & Accacia nilotica (L.) Delile. & Kikar & Mimosaceae & Tree & $\begin{array}{l}\text { Gum is used as antihelmentic agent, while } \\
\text { flower along with sugar is used for cough. }\end{array}$ \\
\hline$(15)$ & Acacia modesta Wall. & Palosa & Mimosaceae & Tree & $\begin{array}{l}\text { Gum is used for impotency and as tonic. Wood } \\
\text { is used for fuel. }\end{array}$ \\
\hline$(16)$ & Amaranthus viridis $\mathrm{L}$. & Ganhar & Amaranthaceae & Herb & $\begin{array}{l}\text { Leaves are cooked as vegetable. Young plants are } \\
\text { also used as fodder. Dry plants are used as fuel. }\end{array}$ \\
\hline (17) & $\begin{array}{l}\text { Aesculus indica (Wall. ex } \\
\text { Camb.) Hook.f. }\end{array}$ & Jawaz & Sapindaceae & Tree & $\begin{array}{l}\text { Fruit is used in abdominal pain. Leaves are used } \\
\text { as fodder for cattle. Wood is used for furniture, } \\
\text { as timber, and fuel wood. }\end{array}$ \\
\hline$(18)$ & Buxus wallichiana Baillon & Shamshad & Buxaceae & & Leaves are used as purgative. \\
\hline$(19)$ & Berberis lyceum Royle. & Kwaray & Berberidaceae & Shurb & $\begin{array}{l}\text { Root bark is used for treatment of hepatitis, } \\
\text { blood purifier, in throat infection, and in } \\
\text { asthma. The plant is also used as fuel. }\end{array}$ \\
\hline$(20)$ & Cuscuta reflexa Roxb. & Paprha (Zelai) & Cuscutaceae & Herb & $\begin{array}{l}\text { Stem is used for fever and skin itching, also used } \\
\text { as antifertility agent. }\end{array}$ \\
\hline$(21)$ & Cupressus sempervirence L. & Sarwa & Cupressaceae & Tree & $\begin{array}{l}\text { The fruit is used as warming agent, } \\
\text { anthelmintic, and astringent. Cultivated in } \\
\text { gardens as ornamental tree. Wood is used as } \\
\text { fuel. }\end{array}$ \\
\hline$(22)$ & $\begin{array}{l}\text { Cotoneaster nummularia Fiseh } \\
\text { \& Mey. }\end{array}$ & Kharawa & Rosaceae & Tree & $\begin{array}{l}\text { Fruit is used as astringent and expectorant. } \\
\text { Wood is used as fuel. Leaves are used as fodder } \\
\text { for cattle. }\end{array}$ \\
\hline$(23)$ & $\begin{array}{l}\text { Cotoneaster microphyllus Wall. } \\
\text { Ex Lindley. }\end{array}$ & Mamanrha & Rosaceae & Tree & $\begin{array}{l}\text { Fruit is edible. Stolons are used as haemostatic. } \\
\text { Wood used as fuel. }\end{array}$ \\
\hline$(24)$ & Chenopodium ambrosioides L. & $\begin{array}{l}\text { Skhabotay (Kamasal } \\
\text { Bhang) }\end{array}$ & Chenoppdiaceae & Herb & $\begin{array}{l}\text { Juice of shoot is used for fever, especially for } \\
\text { malarial fever. }\end{array}$ \\
\hline
\end{tabular}


Table 1: Continued.

\begin{tabular}{|c|c|c|c|c|c|}
\hline S/no. & Botanical name & Local name & Family & Habit & Ethnobotanical uses \\
\hline$(25)$ & Chenopodium album $\mathrm{L}$. & Sarmay & Chenoppdiaceae & Herb & $\begin{array}{l}\text { Leaves and young shoots are cooked as } \\
\text { vegetable. }\end{array}$ \\
\hline$(26)$ & Celtis australis. & Tagha & Ulmaceae & Tree & $\begin{array}{l}\text { Fruit is edible. Wood is used in furniture, for } \\
\text { timber and as fuel. }\end{array}$ \\
\hline$(27)$ & Cichorium intybus Linn. & Han & Asteraceae & Herb & $\begin{array}{l}\text { Leaves are used as anti-inflammatory and for } \\
\text { hepatic complaints. }\end{array}$ \\
\hline$(28)$ & Cedrela serrata Royle. & Shnai & Meliaceae & Tree & $\begin{array}{l}\text { Leaves are used for digestive problems, as } \\
\text { fodder for cattle. Wood is used as fuel. }\end{array}$ \\
\hline (29) & Carthamus oxycantha M. Bieb. & Azghibotay & Asteraceae & Herb & $\begin{array}{l}\text { Leaves are used as antiseptic. Seed are used for } \\
\text { skin itching. }\end{array}$ \\
\hline$(30)$ & $\begin{array}{c}\text { Caralluma tuberculata N.E. } \\
\text { Brown. }\end{array}$ & Pamankay & Asclepiadaceae & Herb & Cooked as vegetable. Juice is used for diabetes. \\
\hline$(31)$ & $\begin{array}{c}\text { Capsella bursa-pastoris. (L.) } \\
\text { Medic. }\end{array}$ & Bambessa & Brasssicaceae & Herb & $\begin{array}{l}\text { The leaves and flowering tops are cooked as } \\
\text { vegetables and also used as fodder for cattle. } \\
\text { The plant is also used as salad. }\end{array}$ \\
\hline$(32)$ & Cannabis sativa Linn. & Bhang & Cannabinaceae & Herb & $\begin{array}{l}\text { Juice of leaves is used for treating malaria and to } \\
\text { relieve pain. Leaves are used for male } \\
\text { impotency. Also used for flatulence and colic } \\
\text { pain. Female plant is used in making hashish } \\
\text { (chars). }\end{array}$ \\
\hline$(33)$ & Cana indica Linn. & Tasfa Botay & Cannaceae & Shurb & $\begin{array}{l}\text { Cultivated as ornamental and also used for } \\
\text { making hedges. }\end{array}$ \\
\hline$(34)$ & $\begin{array}{l}\text { Calotropis procera (Wild) R. } \\
\text { Brown. }\end{array}$ & Spalmai & Asclepiadaceae & Herb & $\begin{array}{l}\text { Paste of leaves in oil is used as pain killer, to } \\
\text { cure skin itch, and scabies. The root bark is used } \\
\text { for the treatment of cholera and constipation. }\end{array}$ \\
\hline$(35)$ & Cynodon dactylon (L.) Pers. & Kabal & Poaceae & Herb & $\begin{array}{l}\text { Grown in lawns, as fodder for grazing cattle. } \\
\text { Crushed shoots are used as haemostatic. }\end{array}$ \\
\hline$(36)$ & $\begin{array}{l}\text { Duchesnea indica (Andr) } \\
\text { Folke. }\end{array}$ & Da Zmake thooth. & Rosaceae & Herb & $\begin{array}{l}\text { Fruit is used as tonic, especially, as cooling } \\
\text { agent. Fruit juice is used for eye infections. }\end{array}$ \\
\hline$(37)$ & Dodonea viscosa (L.) Jacq. & Ghwarhaskay & Sapindaceae & Shrub & $\begin{array}{l}\text { Ash is used to treat burns and skin infections. } \\
\text { Water extracts of leaves is used as antihelmentic. } \\
\text { Plant is used as thatching material in building of } \\
\text { houses. The plant is a good source of fuel for the } \\
\text { locals. }\end{array}$ \\
\hline$(38)$ & Diospyrus kaki L. & Sur Amlok & Ebenaceae & Tree & $\begin{array}{l}\text { Fruit is edible and also a source of income for } \\
\text { the locals, sold locally and in other parts of the } \\
\text { country. Leaves are used as fodder for cattle. } \\
\text { Wood is used as fuel. }\end{array}$ \\
\hline (39) & Diospyrus lotus L. & Tor Amlok & Ebenaceae & Tree & $\begin{array}{l}\text { Fruit is edible and also used in diarrhea. Leaves } \\
\text { are used as fodder for goat and sheep. Wood is } \\
\text { used as fuel. }\end{array}$ \\
\hline$(40)$ & Debregeasia saeneb $\mathrm{F}$. & Ijrhrai & Urticaceae & Tree & Wood is used as fuel. \\
\hline$(41)$ & Delphinium roylei Munz. & - & Ranunculaceae & Herb & Seeds are used as insecticide. \\
\hline$(42)$ & Daphne macronata Royle. & Lighonay & Thymeleaceae & Shrub & $\begin{array}{l}\text { Leaves are used as purgative. Shoots are used as } \\
\text { fuel. }\end{array}$ \\
\hline$(43)$ & Euphorbia heliscopia Linn. & Mandanrho & Euphorbiaceae & Herb & $\begin{array}{l}\text { Seed are purgative. Latex is used for skin } \\
\text { diseases and to extract spine from skin. }\end{array}$ \\
\hline$(44)$ & Euphorbia hirta Linn. & Jaghje & Euphorbiaceae & Herb & $\begin{array}{l}\text { Seeds are used as tonic and for the treatment of } \\
\text { diarrhea. }\end{array}$ \\
\hline$(45)$ & Eugenia jamblana Lam. & Jaman & Myrtaceae & Tree & $\begin{array}{l}\text { Fruit is edible and used for liver problems. Bark } \\
\text { is used as mouth wash, seed are used for } \\
\text { diabetes, leaves are used in dysentery. }\end{array}$ \\
\hline$(46)$ & Equisitum arvense $\mathrm{L}$. & Bandakay & Equisetaceae & Herb & $\begin{array}{l}\text { Used for inflammation of urinary bladder and } \\
\text { other urine problems. }\end{array}$ \\
\hline$(47)$ & Eupharsia malaica Wetts & Ghutyalay & Scrophulariaceae & Herb & Cooked as vegetable. \\
\hline
\end{tabular}


Table 1: Continued.

\begin{tabular}{|c|c|c|c|c|c|}
\hline S/no. & Botanical name & Local name & Family & Habit & Ethnobotanical uses \\
\hline$(48)$ & $\begin{array}{c}\text { Fummaria indica (Hausskn) } \\
\text { Pugsl }\end{array}$ & Krachay (Paprha) & Fumariaceae & Herb & $\begin{array}{l}\text { Used as blood purifier, for pimples, and } \\
\text { inflammation of heals and palms. }\end{array}$ \\
\hline$(49)$ & Galium aparine L. & - & Rubiaceae & Climber & $\begin{array}{l}\text { Whole plant is used as diuretic, for urinary tract } \\
\text { problems, and in fever. }\end{array}$ \\
\hline$(50)$ & $\begin{array}{l}\text { Gymnosporia royleana (Wall) } \\
\text { Lawson. }\end{array}$ & Sur Azghay & Celastraceae & Shrub & Seed are used for male impotency. \\
\hline$(51)$ & Ficus palmata Forssk. & Inzar & Moraceae & Tree & $\begin{array}{l}\text { Fruit is edible, eaten fresh as well as dried. The } \\
\text { tree is believed sacred and, therefore, the people } \\
\text { avoid using it as fuel. Latex is used to extract } \\
\text { spine from skin. }\end{array}$ \\
\hline$(52)$ & Foeniculum vulgare Mill. & Kaga & Apiaceae & Herb & $\begin{array}{l}\text { Fruit is used as carminative, used to control } \\
\text { vomiting, and as flavoring agent. }\end{array}$ \\
\hline$(53)$ & Allium sativum $\mathrm{L}$. & Ogakai & Alliaceae & Herb & $\begin{array}{l}\text { Eaten uncooked. Used as spice. Grinded and } \\
\text { mixed with maize floor to prepare spicy bread. }\end{array}$ \\
\hline$(54)$ & $\begin{array}{l}\text { Heracleum candicans Wall.ex } \\
\text { DC. }\end{array}$ & Skhwara & Apiaceae & Herb & Used for cough and throat infections. \\
\hline$(55)$ & Iris germanica L. & & Iridaceae & Herb & $\begin{array}{l}\text { Roots are used elevate body pain. Cultivated on } \\
\text { graves. }\end{array}$ \\
\hline$(56)$ & $\begin{array}{l}\text { Ipomoea purpurea (Linn.) } \\
\text { Roth. }\end{array}$ & Prewata & Convolvulaceae & Herb & Ornamental. \\
\hline$(57)$ & Ipomoea hederacea (L.) Jacq. & Speaker Gul & Convolvulaceae & Herb & Ornamental. \\
\hline$(58)$ & $\begin{array}{c}\text { Indigofera gerardiana Wall. ex } \\
\text { Baker }\end{array}$ & Ghawareja & Papilionaceae & Shrub & $\begin{array}{l}\text { Leaves are used for colic pain. Woods is used as } \\
\text { fuel. Shoots are used for making baskets and } \\
\text { other similar articles. }\end{array}$ \\
\hline$(59)$ & Juglan regia Linn. & Ghuz & Juglandaceae & Tree & $\begin{array}{l}\text { Fruit is edible and consumed as dry fruit. Peel } \\
\text { of bark and roots, locally called Dandasa is used } \\
\text { for cleaning teeth and to colour lips. Wood is } \\
\text { used for furniture and as a timber. }\end{array}$ \\
\hline$(60)$ & Justicia adhatoda L. & Baikarh & Acanthaceae & Shrub & Leaves are used for cough and cold. \\
\hline$(61)$ & Lycopus europaeus Linn. & - & Lamiaceae & & The leaves are used as antiseptics. \\
\hline$(62)$ & Myrtus communis $\mathrm{L}$. & $\begin{array}{l}\text { Asta Ghonay } \\
\text { (Manrho) }\end{array}$ & Myrtaceae & Shrub & $\begin{array}{l}\text { Fruits are edible. Leaves are used in colic and in } \\
\text { diarrhea. }\end{array}$ \\
\hline$(63)$ & Myrsine africana Linn. & - & Myrsinaceae & Shrub & $\begin{array}{l}\text { Leaves are used as blood purifier. Fruit is used as } \\
\text { antihelmintic, for colic pain. Shoots are used for } \\
\text { making hedges. }\end{array}$ \\
\hline$(64)$ & $\begin{array}{c}\text { Monotheca buxifolia (Falc) } \\
\text { A.DC. }\end{array}$ & Gwargurah & Sapotaceae & Shrub & Fruit is edible. Plant is also used as fuel. \\
\hline$(65)$ & $\begin{array}{l}\text { Morus lavaegata Wallich. Ex } \\
\text { Brandis. }\end{array}$ & Shahthooth. & Moraceae & Tree & $\begin{array}{l}\text { Fruit is edible. Leaves are used as fodder for } \\
\text { cattle. }\end{array}$ \\
\hline$(66)$ & Morus alba L. & Spen Thooth & Moraceae & Tree & $\begin{array}{l}\text { Fruit is edible. Leaves are used as fodder for } \\
\text { cattle. Wood is used for making furniture, for } \\
\text { timber, for making agriculture tools and as a } \\
\text { fuel. }\end{array}$ \\
\hline$(67)$ & Morus nigra L. & Tor thooth & Moraceae & Tree & $\begin{array}{l}\text { Fruit is edible. Wood is used in making } \\
\text { furniture, for timber, for making agriculture } \\
\text { tools, and as a fuel. Leaves are used as fodder for } \\
\text { cattle. }\end{array}$ \\
\hline$(68)$ & Mirabilis jalapa Linn. & Gule Badi & Nyctaginaceae & Shrub & $\begin{array}{l}\text { Leaves are used to treat abscess. Root tubers are } \\
\text { used as pain killer and also for treatment of } \\
\text { typhoid. }\end{array}$ \\
\hline$(69)$ & Micromeria biflora Benth. & Shamakay & Lamiaceae & Herb & Leaves used as antiemotic. Also used in flu. \\
\hline$(70)$ & $\begin{array}{l}\text { Mentha longifolia (Linn) } \\
\text { Huds. }\end{array}$ & Venalay & Lamiaceae & Herb & $\begin{array}{l}\text { Leaves are used to reduce gastric acidity, used as } \\
\text { antispasmodic, carminative, and to relieve } \\
\text { abdominal pain. Leaves are widely used to } \\
\text { flavour local food named Gungrhi. }\end{array}$ \\
\hline
\end{tabular}


Table 1: Continued.

\begin{tabular}{|c|c|c|c|c|c|}
\hline S/no. & Botanical name & Local name & Family & Habit & Ethnobotanical uses \\
\hline$(71)$ & Mentha arvensis $\mathrm{L}$. & Phodena & Lamiaceae & Herb & $\begin{array}{l}\text { Leaves are used to reduce gastric acidity and } \\
\text { also used as antispasmodic, carminative, and to } \\
\text { relieve abdominal pain. Also used to make } \\
\text { Chanti and as flavouring agent in a variety of } \\
\text { food items. }\end{array}$ \\
\hline$(72)$ & Melia azedarach $\mathrm{L}$. & Tora Bekanrha & Meliaceae & Tree & $\begin{array}{l}\text { Leaves are used as antiseptic and antibiotic. } \\
\text { Water extracts of leaves is used as antilice and } \\
\text { antidandruff agent. Wood is used for making } \\
\text { furniture and also for burning and for timber } \\
\text { purposes. }\end{array}$ \\
\hline$(73)$ & Matricaria chamomilla Auct. & - & Asteraceae & Herb & $\begin{array}{l}\text { Flowers are used as carminative, in digestive } \\
\text { disorders, and for colic pain. }\end{array}$ \\
\hline$(74)$ & Malva sylvestris $\mathrm{L}$. & Shonchal & Malvaceae & Herb & Cooked as vegetable. \\
\hline$(75)$ & Morchella esculenta Fr. & Gojay & Morchellaceae & Mushroom & $\begin{array}{l}\text { Used as food. Very expensive, sold to earn. } \\
\text { Mainly exported in dry form. }\end{array}$ \\
\hline$(76)$ & Nerum oleander L. & Ghanderay & Apocynaceae & Shrub & $\begin{array}{l}\text { Plant is usually cultivated for ornamental } \\
\text { purposes, leaf aqueous extract is used for skin } \\
\text { itching. }\end{array}$ \\
\hline$(77)$ & Nasturtium officinale R. Br. & Talmera & Brassicaceae & Herb & $\begin{array}{l}\text { Cooked as vegetable. Cooked herb is used in } \\
\text { tetanus. }\end{array}$ \\
\hline$(78)$ & Narcissus poeticus L. & Gule Nargas & Amaryllidaceae & Herb & $\begin{array}{l}\text { Flowers are used for ornamental purposes. } \\
\text { Grown on graves. }\end{array}$ \\
\hline$(79)$ & Oxalis corniculata $\mathrm{L}$. & Nainzakai Tarokai & Oxalidaceae & Herb & $\begin{array}{l}\text { Eaten fresh and used as spice. Used to remove } \\
\text { rust from metallic articles. }\end{array}$ \\
\hline$(80)$ & Onosma hispidum Wall. & Abai Abai & Boraginaceae & Herb & Root is used as purgative. \\
\hline$(81)$ & Olea ferrginea Royle. & Khona & Oleaceae & Tree & $\begin{array}{l}\text { Olive oil is use externally as antiseptic and } \\
\text { anodyne. Leaves are used in diabetes. Wood is } \\
\text { used as fuel and for furniture. Usually cultivated } \\
\text { in graveyards. Has become endangered species. }\end{array}$ \\
\hline$(82)$ & Ocimum basilicum L. & Kashmalay & Lamiaceae & Herb & $\begin{array}{l}\text { Leaves are used in cough and flu. Seed are } \\
\text { added to cold drinks. Also grown as ornament. }\end{array}$ \\
\hline$(83)$ & Pyrus communis $\mathrm{L}$. & Nashpatai & Rosaceae & Tree & $\begin{array}{l}\text { Food is edible. Fruit is source of income, sold } \\
\text { locally and in other parts of the country. Wood } \\
\text { is used as fuel. }\end{array}$ \\
\hline$(84)$ & $\begin{array}{l}\text { Pyrus pashia Buch-ham ex. } \\
\text { Don. }\end{array}$ & Batangi & Rosaceae & Tree & Fruit is edible. Wood is used as fuel. \\
\hline$(85)$ & Punica granatum $\mathrm{L}$. & Anangori. & Punicaceae & Tree & $\begin{array}{l}\text { Fruit is edible. Ash of fruit rind is used in } \\
\text { hepatitis, digestive problems, and urinary } \\
\text { problems. }\end{array}$ \\
\hline$(86)$ & Populus nigra L. & Sperdar & Salicaceae & Tree & $\begin{array}{l}\text { Wood is very useful and used in making } \\
\text { furniture, used in timber. Branches are used as } \\
\text { fuel wood. Leaves as fodder. }\end{array}$ \\
\hline$(87)$ & Portulaca oleracea L. & Zangali Warkhrhay & Portulacaceae & Herb & Cooked as vegetables. Also used as demulcent. \\
\hline$(88)$ & Portulaca quadrifida L. & Zangali Warkhrhay & Portulacaceae & Herb & Cooked as vegetable. \\
\hline$(89)$ & Polygonum aviculare $\mathrm{L}$. & Bandakay & Polygonaceae & Herb & Cooked as vegetable. \\
\hline$(90)$ & Platanus orientalis $\mathrm{L}$. & Chinar & Platanaceae & Tree & $\begin{array}{l}\text { Leaves are used in dysentery. Wood is used for } \\
\text { making furniture, timber, and also as fuel. Dry } \\
\text { leaves are also used as fuel. }\end{array}$ \\
\hline$(91)$ & Plantago lanceolata L. & Jabai & Plantaginaceae. & Herb & $\begin{array}{l}\text { Leaves are used for treatment of dysentery and } \\
\text { diarrhea. Also used as wound dressing and } \\
\text { antiseptic. }\end{array}$ \\
\hline$(92)$ & Plantago major L. & Jabai & Plantaginaceae & Herb & $\begin{array}{l}\text { Leaves are used as tonic and antiseptic, Also } \\
\text { used for fever. }\end{array}$ \\
\hline
\end{tabular}


Table 1: Continued.

\begin{tabular}{|c|c|c|c|c|c|}
\hline S/no. & Botanical name & Local name & Family & Habit & Ethnobotanical uses \\
\hline$(93)$ & Pinus roxburghii Sargent. & Nakhtar & Pinaceae & Tree & $\begin{array}{l}\text { Resin is used as antihelminitic agent. Wood is } \\
\text { used as fuel and timber. Dried leaves locally } \\
\text { called Barwaza are used to spread below mates } \\
\text { in mosques. Dried leaves are also used as } \\
\text { packing material for local fruits (apple, apricot, } \\
\text { peach, and pyrus) }\end{array}$ \\
\hline$(94)$ & Periploca aphylla Decne. & Barrha & Asclepiadaceae & Shrub & $\begin{array}{l}\text { Stem is used as laxative. Milky juice of shoot is } \\
\text { used in fever. }\end{array}$ \\
\hline$(95)$ & Papaver pavoninum Schrenk. & Sur gulay & Papveraceae & Herb & Flowers are used as sedative. \\
\hline$(96)$ & Quercus incana Roxb. & Spin Banj & Fabaceae & Tree & $\begin{array}{l}\text { Fruits are used for controlling excessive } \\
\text { urination and kidney problems, also used for } \\
\text { inflammations. Wood is used as fuel. }\end{array}$ \\
\hline$(97)$ & $\begin{array}{l}\text { Quercus dilatata Lindl. Ex } \\
\text { Royle. }\end{array}$ & Tor Banj & Fabaceae & Tree & $\begin{array}{l}\text { Fruit is used for digestive problems and asthma } \\
\text { Wood is used as fuel. }\end{array}$ \\
\hline$(98)$ & Rumex hastatus D.Don. & Tarokay & Polygonaceae & Herb & $\begin{array}{l}\text { Leaves used as carminative, diuretic, and used } \\
\text { in jaundice. Leaves are cooked as vegetable and } \\
\text { also eaten uncooked. }\end{array}$ \\
\hline (99) & Rumex dentatus. L. & Shalkhay & Polygonaceae & Herb & $\begin{array}{l}\text { Cooked as vegetables. Also used to treat } \\
\text { constipation in cattle. }\end{array}$ \\
\hline$(100)$ & Rubus fruticosus Agg. & Karwarha & Rosaceae & Shrub & $\begin{array}{l}\text { Fruit is edible. Plants are used for making } \\
\text { hedges. }\end{array}$ \\
\hline$(101)$ & $\begin{array}{l}\text { Rosa webbiana Wallich ex } \\
\text { Royle }\end{array}$ & Zangali Gulab & Rosaceae & Shrub & Used for making hedges and as ornament. \\
\hline$(102)$ & Rubus ellipticus Smith. & Pulwarhi & Rosaceae & Shrub & $\begin{array}{l}\text { Fruit is edible and is useful for removal of } \\
\text { kidney stone. Plants are grown for making } \\
\text { hedges. }\end{array}$ \\
\hline$(103)$ & Salix acmophylla L. & Walla. & Salicaceae & Tree & $\begin{array}{l}\text { Leaves are used externally to relieve pain. Wood } \\
\text { is used for furniture, timber, and as fuel. }\end{array}$ \\
\hline$(104)$ & Robinia pseduacacia L. & Kikar & Papilionaceae & Tree & $\begin{array}{l}\text { Wood is used as fuel. Honey bee plant. } \\
\text { Cultivated as road-side shade plant. }\end{array}$ \\
\hline$(105)$ & Ricinus communis $\mathrm{L}$. & Arhanda & Euphorbiaceae & Tree & $\begin{array}{l}\text { Seed oil is used as laxative, applied to swellings } \\
\text { and to treat constipation. Local Hakeems use it } \\
\text { as antidote for arsenic poisoning. Seeds are use } \\
\text { for cough, fever, and headache. }\end{array}$ \\
\hline$(106)$ & $\begin{array}{l}\text { Rabdosia rugosa (Wallich ex. } \\
\text { Benth) Hara. }\end{array}$ & Spaerkay & Lamiaceae & Herb & $\begin{array}{l}\text { Leaves are used in colic. Leaf extract is also used } \\
\text { as vermicide and insecticide. }\end{array}$ \\
\hline & Ranunculus muricatus L. & Ziar Gulay & Ranunculaceae & Herb & Used for treatment of schiatic pain. \\
\hline$(107)$ & $\begin{array}{l}\text { Salvia moorcroftianaWall. ex } \\
\text { Benth. }\end{array}$ & Khar Kwag & Lamiaceae & Herb & Leaves are used commonly to relive pain. \\
\hline$(108)$ & Stelaria media (L.) Vill. & Olalai & Carophyllaceae & Herb & $\begin{array}{l}\text { Plant is cooked as vegetable, also used for } \\
\text { constipation. }\end{array}$ \\
\hline$(109)$ & Sonchus oleraceous L. & Shawdapai & Asteraceae & Herb & $\begin{array}{l}\text { Used as fodder for cattle, believed to enhance } \\
\text { milk production. }\end{array}$ \\
\hline$(110)$ & Sonchus asper L. & Shawdapai & Asteraceae & Herb & Used as fodder for cattle. \\
\hline$(111)$ & Solanum surattense Burm.f. & Marhaghonay & Solanaceae & Herb & $\begin{array}{l}\text { Seed along with mustard oil is used for } \\
\text { treatment of migraine. Ash of plant is used as } \\
\text { tonic and pain killer. }\end{array}$ \\
\hline$(112)$ & Solanum nigrum Auct. & Kach Machu & Solanaceae & Herb & $\begin{array}{l}\text { Fruit is used for inflammation and liver } \\
\text { problems. }\end{array}$ \\
\hline$(113)$ & Silene conidia L. & Mangotey & Caryophyllaceae & Herb & Used as vegetables (SAAG). \\
\hline$(114)$ & Sorghum halepense Pers. & Dadam & Poaceae & Herb & Mature plants are used as fodder for cattle. \\
\hline$(115)$ & $\begin{array}{l}\text { Sarcococca saligna (D.Don) } \\
\text { Muell. Arg. }\end{array}$ & Ladanrh & Busaceae & Shrub & Plant is used for digestive disorders. \\
\hline$(116)$ & Solanum dulcamara L. & Kachmacho & Solanaceae & Herb & $\begin{array}{l}\text { Fruit is used for inflammation and liver } \\
\text { problems. }\end{array}$ \\
\hline
\end{tabular}


TABle 1: Continued.

\begin{tabular}{|c|c|c|c|c|c|}
\hline S/no. & Botanical name & Local name & Family & Habit & Ethnobotanical uses \\
\hline$(117)$ & $\begin{array}{l}\text { Silybum marianum (L.) } \\
\text { Gaertn. }\end{array}$ & Worajakai & Asteraceae & Herb & Flower is used for jaundice and tuberculosis. \\
\hline$(118)$ & Salix babylonica L. & Walla & Salicaceae & Tree & $\begin{array}{l}\text { Leaves are used externally as warming agent to } \\
\text { relieve pain. Wood is used for furniture and } \\
\text { timber, also used as fuel. }\end{array}$ \\
\hline$(119)$ & Sagittaria guyanensis Kunth & - & Alismataceae & Herb & Rhizome is used in skin diseases. \\
\hline$(120)$ & $\begin{array}{l}\text { Typha angustata Bory \& } \\
\text { Chaub. }\end{array}$ & Lukha & Typhaceae & Herb & $\begin{array}{l}\text { Plant is used as thatching material. Leaves are } \\
\text { used as fodder. }\end{array}$ \\
\hline$(121)$ & Trifolium repens $\mathrm{L}$. & Shautal & Papilionaceae & Herb & $\begin{array}{l}\text { Used as fodder for cattle. The seeds are used for } \\
\text { treatment of pimples. }\end{array}$ \\
\hline$(122)$ & Tribulus terrestris $\mathrm{L}$. & Markundai & Zygophyllaceae & Herb & $\begin{array}{l}\text { Seed are used as general tonic, used in urinary } \\
\text { disorders and impotency. }\end{array}$ \\
\hline$(123)$ & Trachyspermum ammi L. & Spairkai & Apiaceae & Herb & $\begin{array}{l}\text { Fruit is used as carminative, digestive, and in } \\
\text { colic pain. }\end{array}$ \\
\hline$(124)$ & Thymus linearis Benth. & Da Payo Shamakay & Lamiaceae & Herb & $\begin{array}{l}\text { Leaves are used in cough, flu, and fever. Seeds are } \\
\text { added to milk to preserve it for longer duration. }\end{array}$ \\
\hline$(125)$ & Thuja orientalis L. & Warha Sarwa & Cupressaceae & Shrub & Ornamental. \\
\hline$(126)$ & Taraxacum officinale Webber. & Ziarh Gulay & Asteraceae & Herb & $\begin{array}{l}\text { Roots are used in diabetes and for kidney } \\
\text { problems. }\end{array}$ \\
\hline$(127)$ & Tagetes minuta L. & Hamesha & Asteraceae & Herb & Ornamental. \\
\hline$(128)$ & Urtica dioica Linn. & Sezonkay & Urticaceae & Herb & $\begin{array}{l}\text { Whole plant is used as diuretic, also used in } \\
\text { jaundice. }\end{array}$ \\
\hline$(129)$ & Verbascum Thapsus L. & Khardag & Scrophulariaceae & Herb & Leaves are used externally to relieve pain. \\
\hline$(130)$ & Voila Canescens Wall. & Banafsha & Violaceae & Herb & $\begin{array}{l}\text { Leaves are used in fevers, flu, and as } \\
\text { expectorant. }\end{array}$ \\
\hline$(131)$ & Voila biflora L. & Banafsha & Violaceae & Herb & $\begin{array}{l}\text { Leaves are used in fevers, flu, and as } \\
\text { expectorant. }\end{array}$ \\
\hline$(132)$ & Vitex negundo L. & Marvandai & Lamiaceae & Shrub & $\begin{array}{l}\text { Leaves are used in digestive problems. Wood is } \\
\text { used as fuel wod. }\end{array}$ \\
\hline$(133)$ & Withania somnifera (L.) Dunal & Koti Lal & Solanaceae & Herb & $\begin{array}{l}\text { Roots bark along with sugar is used as tonic, } \\
\text { galactagogue. Also used to relieve back ache. }\end{array}$ \\
\hline$(134)$ & Xanthium stramarium. Linn. & Jishkay & Asteraceae & $\begin{array}{l}\text { Woody } \\
\text { herb }\end{array}$ & $\begin{array}{l}\text { Leaves are used for treatment of asthma. Stem } \\
\text { ash is used as pain killer. The plant is also used } \\
\text { as fuel. Leaves are grazed by cattle. }\end{array}$ \\
\hline$(135)$ & Zizyphus mauritiana Lam. & Mada Bera & Rhamnaceae & Tree & Fruit is edible. Wood is used as fuel. \\
\hline$(136)$ & Zizyphus sativa Gaertn & Markhanry & Rhamnaceae & Tree & $\begin{array}{l}\text { Fruit is edible. Leaves and fruit are believed as } \\
\text { antibiotic and antidiabetic. Wood is used as fuel } \\
\text { wood. Leaves are grazed by cattle. }\end{array}$ \\
\hline$(137)$ & Zizyhus oxyphyla Edgew & Elanai & Rhamnaceae & Tree & $\begin{array}{l}\text { Fruit is edible. Leaves and fruit are believed to } \\
\text { be antibiotic and antidiabetic. Wood is used as } \\
\text { fuel. Root extract is used for hepatitis. Fruit is } \\
\text { also used as heart tonic. }\end{array}$ \\
\hline$(138)$ & Zanthoxylum armatum DC. & Dambara & Rutaceae & Shrub & $\begin{array}{l}\text { Fruit is used for treating stomach disorders and } \\
\text { also as spices. }\end{array}$ \\
\hline
\end{tabular}

about local names and traditional uses of plants were obtained from local people through direct interviews. Mostly experienced and aged persons, especially elderly women were interviewed. Although interviews were made at random priority was given to the locals of upper parts of the Tehsil, due to their better knowledge of the plants and their frequent uses. Plant specimens were collected, preserved, and identified with the help of flora of Pakistan [13, 14]. Identification of plants was further confirmed through the Herbarium, Department of Botany, University of Peshawar.

\section{Results and Discussion}

Ethnobotany is an integral part of indigenous/local knowledge of a particular society. Different societies or communities have their own knowledge about plants and their uses [15].

In the present study a total of 140 plants were studied for ethnobotanical uses. Of these 133 (95\%) plants were angiosperm, 3 (2.14\%) were gymnosperms, 2 (1.42\%) belonged to each of pteridophytes and fungi. Out of 133 
angiosperms $76(55.63 \%)$ were herbs 17 (12.78\%) were shrubs and $40(30.07 \%)$ were trees. The number of monocot and dicots plants were 127 (95.48\%) and 6 (4.51\%), respectively. Most of the plants were used for multiple purposes. Local generally used these plants for medicinal values, fuel, timber wood, foods and fodder for cattle. Out of these, 91 plants were used for medicinal purposes. The ethnobotanical information obtained are given in Table 1.

In the lower part of the Tehsil Kabal the medical facilities like government hospital, private clinics, and pharmacies are easily accessible so the use of plants for medicinal purposes is not a common feature, and they mainly use herbal drugs for colic pains and digestive problems. But the people living in the upper part of the Tehsil, especially the Qalagai, Manrhai, and Surbala villages where hospitals and other health facilities are not easily available to people, use herbal drugs quite frequently. In the present study, 93 (66.4\%) plants including Artemisia absinthium, Atropa acuminate, Ajuga parviflora, Ajuga bracteosa, Acorus calamus, Acacia modesta, Berberis lyceum, Cichorium intybus, Caralluma tuberculata, Canabis sativa, Calotropis procera, Mirabilis jalapa, Micromeria biflora, Plantago major, and Ricinus communis are used by locals for medicinal purposes. The medicinal values of most of these plants are also reported by Razaq et al. [16], Ibrar et al. [3], Hamayun et al. [17], Manan et al. [18], and Jan et al. [19] from other parts of the country.

Majority of the people of the area are farmers and they also keep cattle, like buffalos, cows, goat, and sheep, and so forth, in homes. Milk and other dairy products are the source of food and income for most of the people living in the upper parts of the study area. To feed the cattle the local also cultivate various fodder crops. Besides these there are numerous wild plants and trees which are used as fodder for cattle. In the present study the plants that were used as fodder count 35 (25\%) which include Avena sativa, Amaranthus viridis, Capsella bursa-pastoris, Cyanodon dactylon, Sonchus asper, Trifolium repens, Sorghum halepense, Melia azedarach, Sonchus oleraceous, Morus alba, Morus nigra, and others.

The folks, especially those living in the upper parts of the area, live a simple life. They use mainly dairy products and plants (vegetables) for food. The plants that are eaten cooked or uncooked by locals include Silene conidia, Amaranthus viridis, Chenopodium album, Caralluma tuberculata, Allium sativum, Malva sylvestris, Nasturtium officinale, Stelaria media, and others.

Most plants, especially trees, are cultivated in the area mainly for fuel wood. Many wild plants are used as fuel. One reason for this is that most of the people of the area are economically not strong and cannot afford LPG as fuel, which is the major alternative for the fuel wood. Plants like Alnus nitida, Artemisia scoparaia, Accacia nilotica, Acacia modesta, Celtis australis, Dodonea viscosa, Melia azedarach, and Alianthus altissima are used as fuel wood by locals. The information gathered in the present study is in line with the works of Ibrar et al. [3], Zabihullah et al. [12], and Khan et al. [20].

The use of plants is an important part in construction of local mud houses and also in making furniture. Alnus nitida, Alianthus altissima, Juglan regia, Morus nigra, Morus alba,
Melia azedarach, and others are locally used as timber and for making furniture. Plants like Artemisia scoparaia and Dodonea viscosa are used as thatching material in construction of muddy houses.

The preset study reveals that the investigated area is under great biotic pressure in the form of deforestation and overgrazing. Woody plants have been damaged due to poor management. There is a dire need to conserve the resources of the area for sustainable use by the locals. The area has a rich potential for wildlife and medicinal plants, and as rangeland, but ecological management including protection is required so that future generation are made happy with natural resources.

\section{References}

[1] A. C. Allem, "Ethnobotanical testimony on the ancestors of cassava (Manihot esculenta Crantz. subsp.esculenta)," Plant Genetic Resources Newsletter, vol. 123, pp. 19-22, 2000.

[2] M. Parada, E. Carrio, M. A. Bonet, and J. Valles, "Ethnobotany of the Alt Empordà region (Catalonia,Iberian Peninsula): plants used in human traditionamedicine," Journal of Ethnopharmacology, vol. 124, no. 3, pp. 609-618, 2009.

[3] M. Ibrar, F. Hussain, and A. Sultan, "Ethnobotanical studies on plant resources of Ranyal Hills, District Shangla, Pakistan," Pakistan Journal of Botany, vol. 39, no. 2, pp. 329-337, 2007.

[4] R. Govaerts, "How many species of seed plants are there?" Taxon, vol. 50, no. 4, pp. 1085-1090, 2001.

[5] R. A. Halberstein, "Medicinal plants: historical and cross-cultural usage patterns," Annals of Epidemiology, vol. 15, no. 9, pp. 686-699, 2005.

[6] A. M. Abbasi, M. A. Khan, M. Ahmad et al., "Ethnobotanical study of wound healing herbs among the tribal communities in Northern Himalaya ranges district Abbottabad, Pakistan," Pakistan Journal of Botany, vol. 42, no. 6, pp. 3747-3753, 2010.

[7] M. Kamal, S. M. Wazir, M. Hassan et al., "Ethnobotanically important plants of district Bannu, Pakistan," Pakistan Journal of Political Science, vol. 15, no. 2, pp. 87-93, 2009.

[8] H. Ali and M. Qaiser, "The ethnobotany of chitral valley, pakistan with particular reference to medicinal plants," Pakistan Journal of Botany, vol. 41, no. 4, pp. 2009-2041, 2009.

[9] F. Hussain, M. Shah, and H. Sher, "Traditionnal resource evaluation of some plants of Mastuj, District Chitral, Pakistan," Pakistan Journal of Botany, vol. 39, no. 2, pp. 339-354, 2007.

[10] E. Bukhsh, S. A. Malik, and S. S. Ahmad, "Estimation of nutritional value and trace elements content of Carthamus oxyacantha, Eruca sativa and Plantago ovata," Pakistan Journal of Botany, vol. 39, no. 4, pp. 1181-1187, 2007.

[11] R. A. Qureshi, M. A. Ghufran, S. A. Gilani et al., "Ethnobotanical studies of selected medicinal plants of Sudhan gali and Ganga Chotti hills, District Bagh, Azad Kashmir," Pakistan Journal of Botany, vol. 39, no. 7, pp. 2275-2283, 2007.

[12] Q. Zabihullah, A. Rashid, and N. Akhtar, "Ethnobotanical survey in Kot-Manzaray Baba valley, Malakand Agency, Pakistan," Pakistan Journal of Political Science, vol. 12, no. 2, pp. 115-121, 2006.

[13] E. Nasir and S. I. Ali, Flora of Pakistan National Herbarium, NARC, Islamabad, Pakistan, 1971-1995.

[14] S. I. Ali and M. Qaiser, Flora of Pakistan, Department of Botany, University of Karachi, 1995-2004.

[15] M. E. Osawaru and F. M. Dania-Ogbe, "Ethnobotanical studies of West African okra [abelmoschus caillei (a. chev) stevels] 
from some tribes of south western Nigeria," Science World Journal, vol. 5, no. 1, 2010.

[16] A. Razaq, A. Rashid, H. Ali, H. Ahmad, and M. Islam, "Ethnomedicinal potential of plants of Changa Valley district Shangla, Pakistan," Pakistan Journal of Botany, vol. 42, no. 5, pp. 3463-3475, 2010.

[17] M. Hamayun, S. Afzal, and M. A. Khan, "Ethnopharmacology, indigenous collection and preservation techniques of some frequently used medicinal plants of Utror and Gabral, district Swat, Pakistan," African Journal of Traditional, Complementary and Alternative Medicines, vol. 3, no. 2, pp. 57-73, 2006.

[18] Z. Manan, A. Sirajuddin, A. Razzaq, M. Islam, and Ikramullah, "Diversity of medicinal plants in Wari Subdivision District Upper Dir, Pakistan," Pakistan Journal of Political Science, vol. 13, no. 1, pp. 21-28, 2007.

[19] G. Jan, M. A. Khan, F. Gul et al., "Ethnobotanical study of common weeds of Dir Kohistan Valley, Khyber Pakhtoonkhwa, Pakistan," Pakistan Journal of Weed Science Research, vol. 16, no. 1, pp. 81-88, 2010.

[20] S. U. Khan, S. M. Wazir, M. Subhan et al., "Some of the ethnobotanically important plants of F.R. Bannu, NWFP, Pakistan," Pakistan Journal of Political Science, vol. 15, no. 1, pp. 81-85, 2009. 

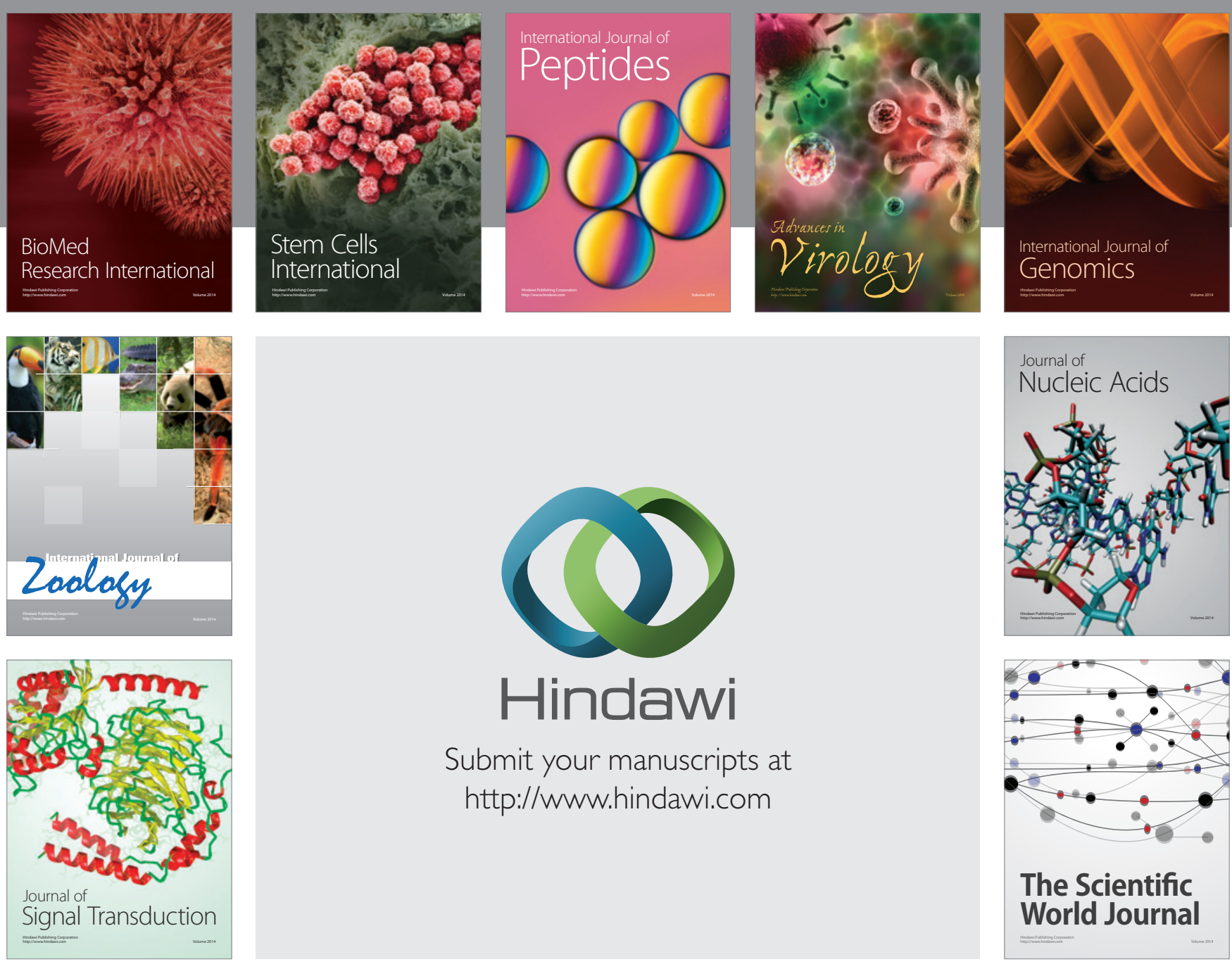

Submit your manuscripts at

http://www.hindawi.com
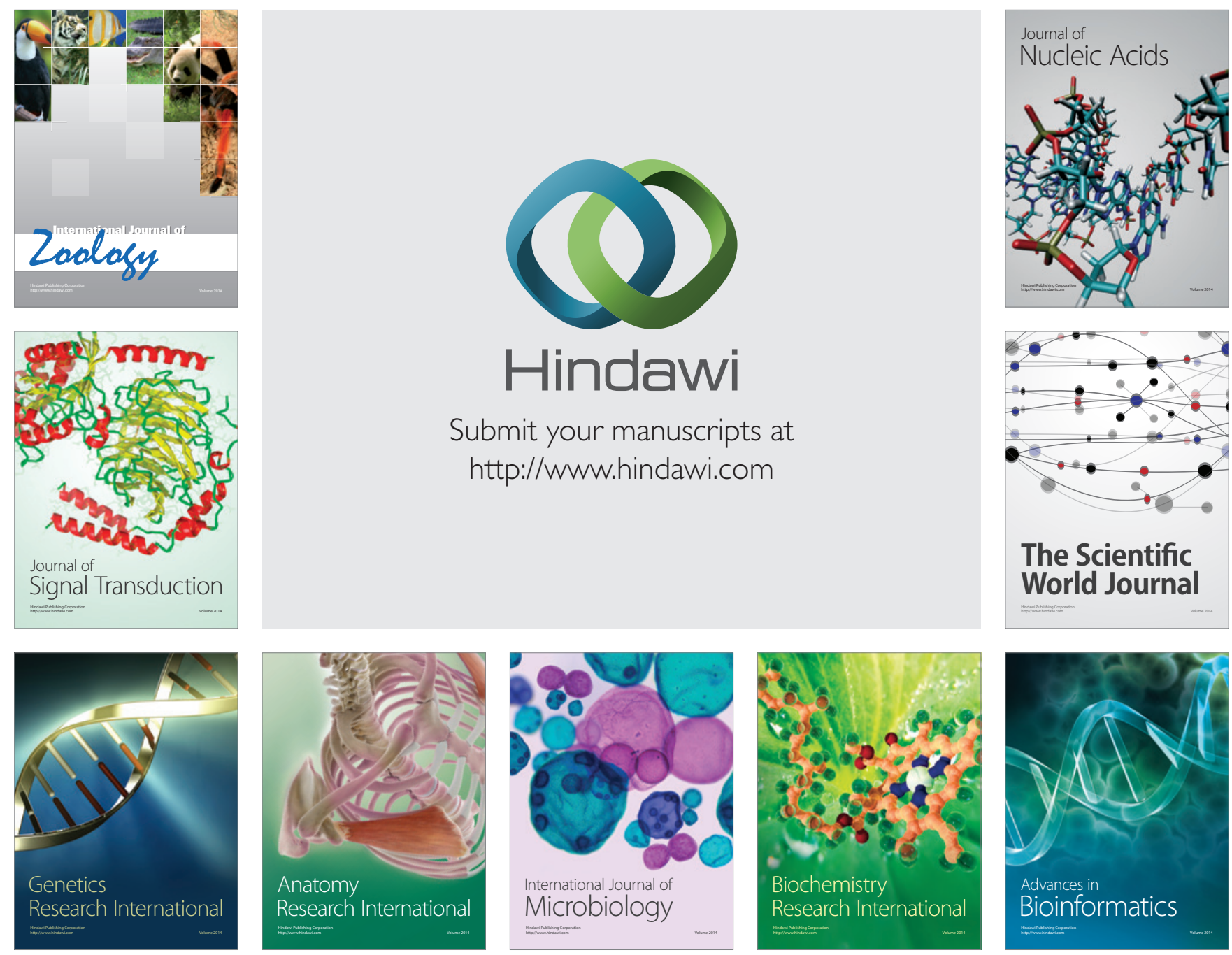

The Scientific World Journal
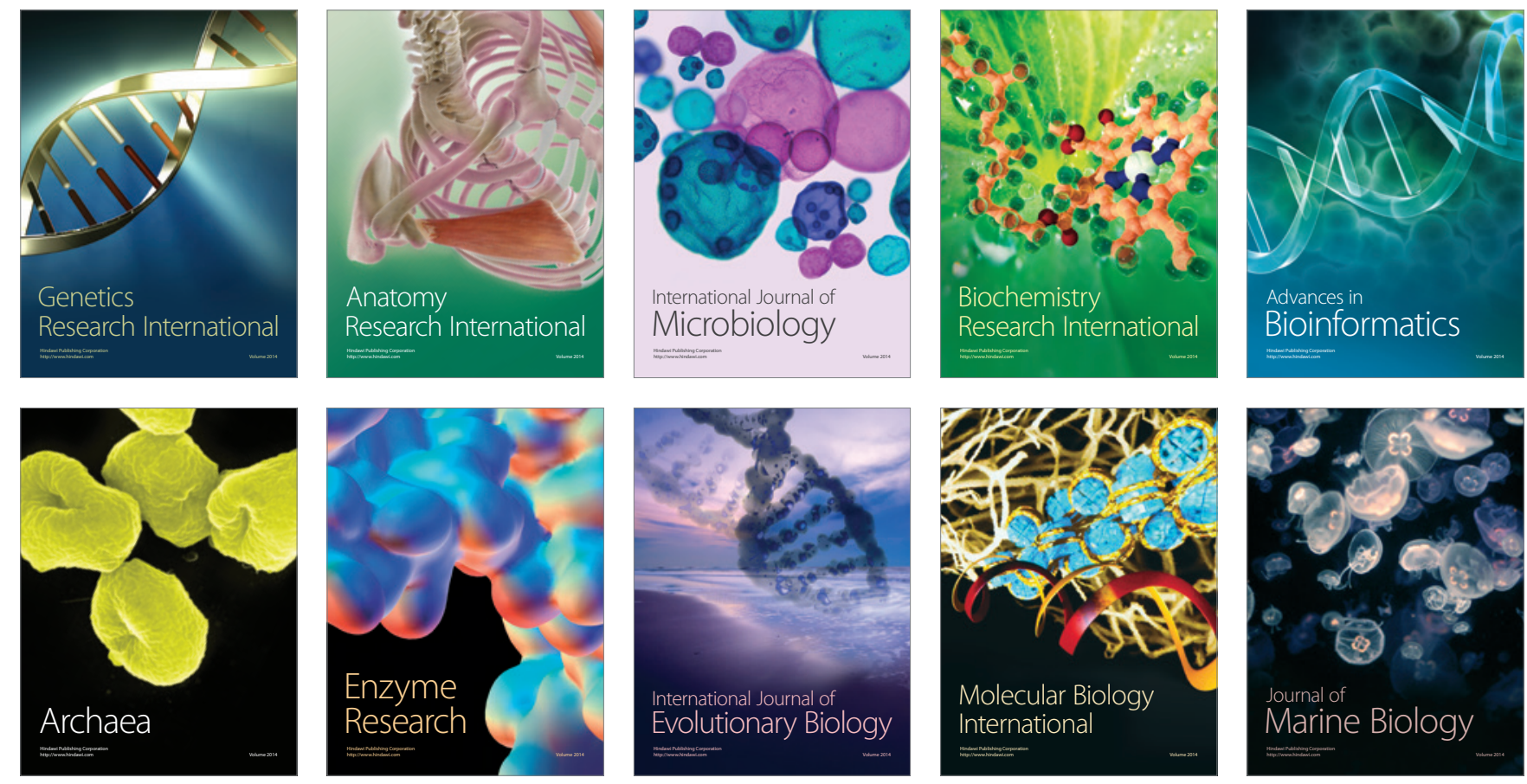